Nada M Al-Sayagh BDS, MSc (Asst Prof.)

\section{A Cephalometric Comparison of Pharynx and Soft Palate in Iraqi Adolescents and Adults Population}

Dept of Pedod, orthod, and Prev Dentistry College of Dentistry, University of Mosul

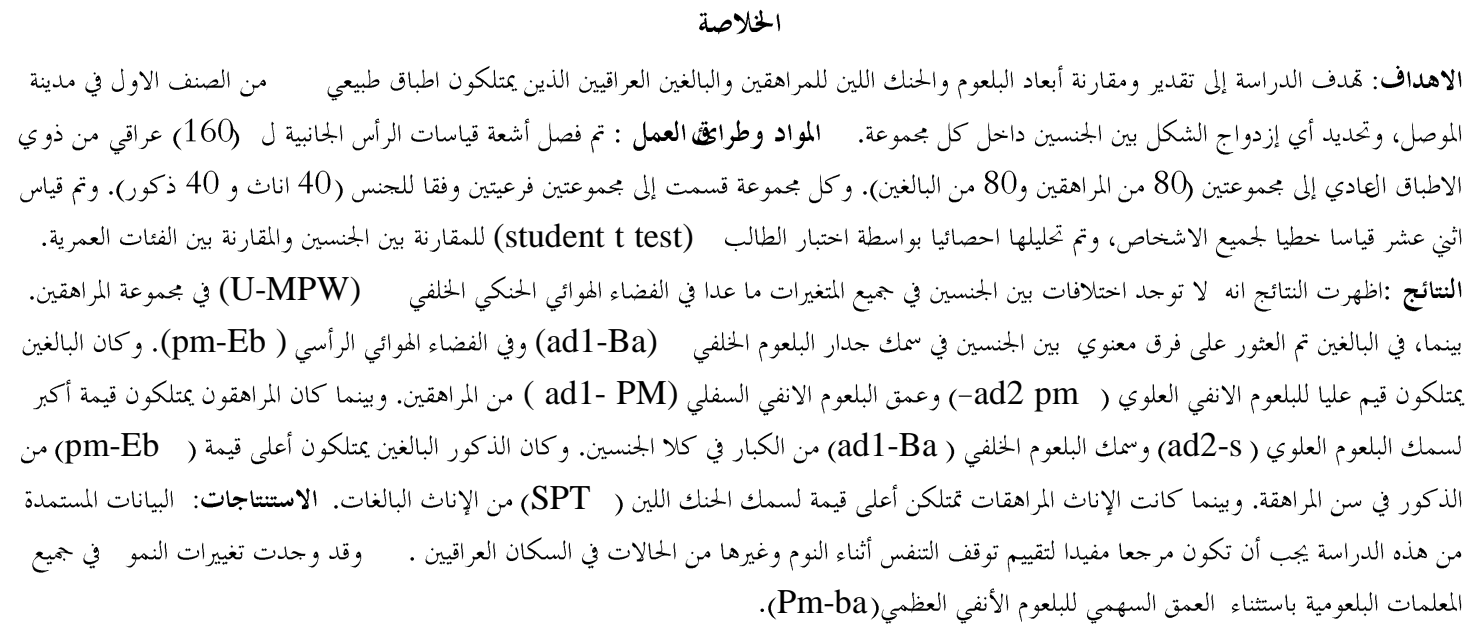

\begin{abstract}
Aims: This paper aims to estimate and compare the pharynx and soft palatal dimensions of Iraqi adolescent and adults with class I normal occlusion at Mosul City and to identify any gender dimorphism within each group. Materials and Methods: Lateral cephalometric radiographs of 160 normal Iraqis what were separated into two groups (80 adolescents and 80 adults). Each group was additionallydivided into two subgroups according to gender ( 40 of each gender). Twelve linear measurements were made in all subjects; gender dimorphism and comparison between two age groups were analysed by students $t$ test.Results:No gender differences in all variables except in retropalatal airway space (UMPW) in the adolescents group. While, in the adults the only significant gender differences were found in the thickness of posterior nasopharyngeal wall (ad1-Ba)and in the vertical airway space (Pm$\mathrm{Eb})$.The adults had significantly larger values for superior nasopharyngeal(pm-ad2) and inferior nasopharyngeal depth (pm-ad1) than adolescents. While ,adolescents had larger value for superior nasopharyngeal thickness (ad2-s) and posterior nasopharyngeal thickness(ad1-Ba) than adults in both genders .The adult male had a higher value for (Pm-Eb) than adolescent male .While , adolescent female had a higher value for soft palate thickness (SPT) than adult female. Conclusions: Data derived from this study should be a useful reference for assessment of sleep apnea and other conditions in the Iraqi population.Developmental changes were found in all nasopharyngeal parameters except the Pm-ba(sagittal depth of the bony nasopharynx).
\end{abstract}

Keywords: Cephalometry, pharynx,soft palate, adults, adolescents.

Al-Sayagh NM. A Cephalometric Comparison of Pharynx and Soft Palate in Iraqi Adolescents and Adults Population. Al-Rafidain Dent J. 2012; 12(1): 32-42.

Received: $3 / 6 / 2010 \quad$ Sent to Referees: $6 / 6 / 2010$

Accepted for Publication: 7/7/2010

\section{INTRODUCTION}

The pharynx is a tube-shaped structure that extends superoinferiorly from the cranial base to the level of the inferior surface of the sixth cervical vertebra. ${ }^{(1)}$ It lies dorsal to the nasal and mouth cavity and is cranial to the esophagus, larynx, and tra- chea. The pharynx can be anatomically separated into three parts: the nasopharynx, oropharynx, and hypopharynx. In a midsagittal image, the nasopharynx extends from the nasal turbinates to the hard palate; the oropharynx can be subdivided into the retropalatal pharynx, from the 
hard palate to the caudal margin of the soft palate, and the retroglossal pharynx, which extends from the caudal margin of the soft palate to the base of the epiglottis; and the hypopharynx is from the base of the epiglottis to the larynx. ${ }^{(2)}$ The pharynx plays an important role in respiration and deglutition.

Significant relationships between the pharyngeal structures and both dentofacial and craniofacial structures have been reported..$^{(3,4)}$

Interpretation of the significance of variations in growth and function depends on an understanding of normal developmental changes. We can benefit from such information in planning treatment and further investigations into breathingdisordered diseases. ${ }^{(5)}$ Cephalometric radiographs have been used for many years to evaluate facial growth and development $^{(6,7)}$ and for assessment of the airway in the craniofacial syndromes ${ }^{(8)}$ in patient with obstructive sleep apnea ${ }^{(9,10)}$ and following orthognathic surgery. ${ }^{(11-13)}$ Several studies have assessed the anatomic conformation of the upper airway with more sophisticated and expensive techniques $^{(14,15)}$ but Cephalometry is ,however, less expensive, more useful, easily achieved with reduced radiation. ${ }^{(16)} \mathrm{Ce}$ phalometric measurements of the airway vary according to ethnic group and sex. ${ }^{(17,18)}$ However there are no data available on the cephalometric comparison of pharynx and soft palate between Iraqi adolescents and adults at Mosul City. Therefore the aims of this study were three folds; 1 . To assess the cephalometric variables of nasopharynx, oropharynx and larynopharynx including soft palate in the adolescents and adults Iraqi population in mosul city. 2. To identify any gender dimorphism in these variables.3) to investigate any differences in the pharynx and soft palate measurements between adolescents and adults in each gender.

\section{MATERIALS AND METHODS}

The sample of this study consisted of 160 subjects distributed into two Groups; 80 adults (40 of each gender) aged 20-30 years old selected from students at Mosul University and 80 adolescents (40 of each gender) aged 12-16 years old. The inclu- sion criteria for the subjects were as follows: All permanents teeth in both jaws present except third molars; no significant medical history; no history of trauma, no previous orthodontic, prosthodontic treatment and no maxillofacial or plastic surgery' Normal visual harmony of facial and skeletal profile. Bilateral class I molar and canine relationship with harmonious overjet and over bite (2-4). No crowding or spacing and no transverse discrepancies. ${ }^{(18)}$

A lateral cephalometric radiograph was taken for each subject under Rigidly Standardized condition. The subjects were asked not to swallow, not to move their heads and tongues, and to contact their teeth lightly with the lips In light contact while the radiographs were being exposed.with,using S.S White cephalometric machine with a Whehmer Cephalostate (mode-W-105A) .

Lateral skull radiographs were traced on acetate paper and 15 hard and soft tissue cephalometric points were registered yielding 12 linear measurements. The measurements were performed manually by the same person using a ruler to the nearest $0.5 \mathrm{~mm}$.

The following points used in this study according toCharoenworaluck ${ }^{(19)}$ :

1. S (sella): The geometric center of the sella tursica. 2. N (nasion): The most anterior point on the frontonasal suture. 3 . $\mathrm{Ba}$ (basion): The most anterior inferior point on the margin of the foramen magnum. 4. ANS (anterior nasal spine): The tip of the bony anterior nasal spine at the inferior margin of the piriform aperture. 5 . PM (pterygomaxillary or posterior nasal spine PNS): The most posterior point on the bony hard palate in the mid sagittal plane. 6. So: Mid-point of distance sellabasion. 7. B-point (supra mental): The deepest (most posterior) midline point on the bony curvature of the anterior mandible between the infradentale and ponion. 8. Go (Gonion): The most posterior inferior point on the outline of the angle of the mandible. 9. Ad1: Intersection of the line $\mathrm{Pm}-\mathrm{Ba}$ and the posterior nasopharyngeal wall.10. ad2: Intersection of the line PmSo and the posterior nasopharyngeal line.11.UPW (upper pharyngeal wall): A point on the posterior pharyngeal 
identified by an extension of the palatal (ANS-PNS) plane. 12. MPW (middle pharyngeal wall): A point on the posterior pharyngeal wall identified by drawing a line from $U$ to the posterior pharyngeal wall parallel to Go-B line.13. LPW (lower pharyngeal wall): A point on the posterior pharyngeal wall identified by an extension of a line through $\mathrm{Eb}$ drawn parallel to the SN plane.14. U (tip of uvula): The most posterior - inferior point of uvula.15. Eb (base of epiglottis): The deepest point of the epiglottis.

Linear measurements used in this study:

Nasopharyngeal parameters:

1. Pm-ad2 (superior nasopharyngeal depth), 2. Ad2-So (thickness of the soft tissue on the superior nasopharynx), 3. Pm-ad1(inferior nasopharyneal depth), 4. Ad1-ba (thickness of the soft tissue on the posterior nasopharyngeal wall), 5. Pm-ba (sagittal depth of the bony nasopharynx).

Oropharyngeal parameters:

Pm-UPW (nasopharyngeal space), UMPW (retro palatal airway space), MAS (middle airway space along line to the Go$\mathrm{B}$ line to the posterior pharyngeal wall), Eb-LMW (hypopharyngeal space), Pm-Eb (vertical airway length).

Soft palatal parameters:

SPL (U-Pm) soft palate length, SPT (Pm-U) soft palate thickness.

All statistical analyses were performed using the Stastical Package for Social Sciences (SPSS for windows 98, version 11.0 SPSS Inc., Chicago). The mean and standard deviation for each variable in all groups were calculated. Student's $t$-test was used to determine whether significant differences existed between males and females and also t test used to compare between adolescents and adults in males and females groups.

\section{RESULTS}

The descriptive statistics of pharynx and soft palate with comparison between genders in the adolescents and adults are shown in Table (1) and Table (2) respectively. There were no significant differences in all variables except for the retropalatal airway space (U-MPW) in which the adolescents female had larger value than male while the adult male had larger values for the thickness of soft tissue on the posterior nasopharyngeal wall (ad1$\mathrm{Ba}$ ) and vertical airway space (Pm-Eb) than female.

The descriptive statistics of pharynx and soft palate for the total sample in the adolescents and adults are illustrated in Table (3) and the comparison between adolescents and adults group in males and females are illustrated in Tables (4) and (5) respectively. The adults had a significantly higher value for (Pm-ad2) and (Pmad1), while the adolescents had higher value for (ad2-So) and (ad1-Ba) than adults in both genders.In addition, the adult male had higher value for (Pm-Eb) than adolescent male as shown in Table (4), while adolescent female had higher value for (SPT) than adult female (Table 5). 
Table (1): Comparison of pharynx and soft palate between males and females in adolescents.

\begin{tabular}{|c|c|c|c|c|c|c|c|c|}
\hline & Variable & $\begin{array}{l}\text { Gen } \\
\text { der }\end{array}$ & $\begin{array}{l}\text { Mini- } \\
\text { mum }\end{array}$ & $\begin{array}{l}\text { Maxi- } \\
\text { mum }\end{array}$ & Mean & SD & T-Test & $\begin{array}{l}\text { Signi- } \\
\text { ficance }\end{array}$ \\
\hline \multirow{10}{*}{ 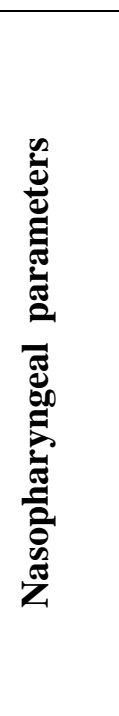 } & (Pm-ad2) & M & 14.00 & 26.00 & 19.67 & 4.15 & \multirow[b]{2}{*}{-.764} & \multirow[b]{2}{*}{.455} \\
\hline & $\begin{array}{l}\text { Superior nasopha- } \\
\text { ryngeal depth }\end{array}$ & $\mathrm{F}$ & 17.00 & 27.00 & 20.95 & 3.15 & & \\
\hline & (Ad2-So) & M & 16.00 & 29.00 & 25.72 & 4.06 & \multirow[b]{2}{*}{1.845} & \multirow[b]{2}{*}{-.83} \\
\hline & $\begin{array}{l}\text { Superior nasopha- } \\
\text { ryngeal thickness }\end{array}$ & $\mathrm{F}$ & 18.00 & 27.50 & 22.90 & 2.50 & & \\
\hline & \multirow{2}{*}{$\begin{array}{l}\text { (Pm-ad1) } \\
\text { Inferior nasopha- } \\
\text { ryngeal depth }\end{array}$} & M & 20.00 & 31.00 & 27.10 & 3.55 & \multirow[b]{2}{*}{-.424} & \multirow[b]{2}{*}{.676} \\
\hline & & $\mathrm{F}$ & 20.00 & 33.00 & 27.85 & 4.32 & & \\
\hline & \multirow{4}{*}{$\begin{array}{l}\text { (Ad1-Ba ) } \\
\text { Posterior naso pha- } \\
\text { ryngeal thickness. } \\
\text { (Pm-Ba) } \\
\text { Sagittal depth of } \\
\text { bony nasopharynx }\end{array}$} & M & 20.00 & 30.00 & 24.80 & 3.39 & \multirow[b]{2}{*}{.844} & \multirow[b]{2}{*}{.410} \\
\hline & & $\mathrm{F}$ & 15.00 & 34.00 & 23.25 & 4.72 & & \\
\hline & & M & 37.00 & 61.00 & 49.70 & 6.34 & \multirow[b]{2}{*}{-.589} & \multirow[b]{2}{*}{.563} \\
\hline & & $\mathrm{F}$ & 45.00 & 58.00 & 51.10 & 4.03 & & \\
\hline \multirow{10}{*}{ 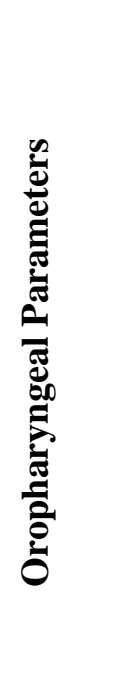 } & \multirow{5}{*}{$\begin{array}{l}\text { (Pm-UPW) } \\
\text { Nasopharyngeal } \\
\text { space. } \\
\text { (U-MPW) } \\
\text { Retropalatal airway } \\
\text { space } \\
\text { (MAS) }\end{array}$} & M & 23.00 & 33.00 & 28.50 & 3.19 & \multirow[b]{2}{*}{-1.135} & \multirow[b]{2}{*}{.194} \\
\hline & & $\mathrm{F}$ & 25.00 & 36.00 & 30.60 & 3.74 & & \\
\hline & & M & 6.00 & 13.00 & 10.45 & 2.35 & \multirow[b]{2}{*}{-2.485} & \multirow[b]{2}{*}{-.23} \\
\hline & & $\mathrm{F}$ & 8.50 & 21.00 & 14.00 & 3.86 & & \\
\hline & & M & 8.00 & 18.00 & 12.45 & 3.13 & \multirow[b]{2}{*}{-1.685} & \multirow[b]{2}{*}{.109} \\
\hline & $\begin{array}{l}\text { Middle airway } \\
\text { space. }\end{array}$ & $\mathrm{F}$ & 9.00 & 20.00 & 15.00 & 3.62 & & \\
\hline & \multirow{4}{*}{$\begin{array}{l}\text { (Eb-LPW) } \\
\text { Hypopharyngeal } \\
\text { space. } \\
\text { (Pm-Eb) } \\
\text { Vertical airway } \\
\text { space }\end{array}$} & M & 7.00 & 25.00 & 15.45 & 6.58 & \multirow[b]{2}{*}{-1.548} & \multirow[b]{2}{*}{.139} \\
\hline & & $\mathrm{F}$ & 12.00 & 26.00 & 19.1 & 3.50 & & \\
\hline & & M & 55.00 & 65.50 & 60.85 & 3.36 & & \\
\hline & & $\mathrm{F}$ & 45.00 & 70.00 & 58.6 & 6.88 & .929 & .365 \\
\hline \multirow{4}{*}{ 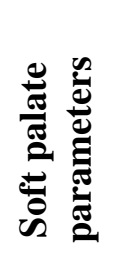 } & (SPL) & M & 27.00 & 48.00 & 36.35 & 5.41 & \multirow[b]{2}{*}{1.047} & \multirow[b]{2}{*}{.309} \\
\hline & Soft palate length. & $\mathrm{F}$ & 26.00 & 40.00 & 33.90 & 5.04 & & \\
\hline & (SPT) & M & 8.00 & 12.50 & 10.20 & 1.29 & \multirow[b]{2}{*}{-.850} & \multirow[b]{2}{*}{.407} \\
\hline & $\begin{array}{l}\text { Soft palate thick- } \\
\text { ness. }\end{array}$ & $\mathrm{F}$ & 9.00 & 13.50 & 10.75 & 1.58 & & \\
\hline
\end{tabular}

**All measurements are in millimeters number for each gender $=40$

* Significant difference at $p \leq 0.05$ 
Table (2): Comparison of pharynx and soft palate between males and females in adult.

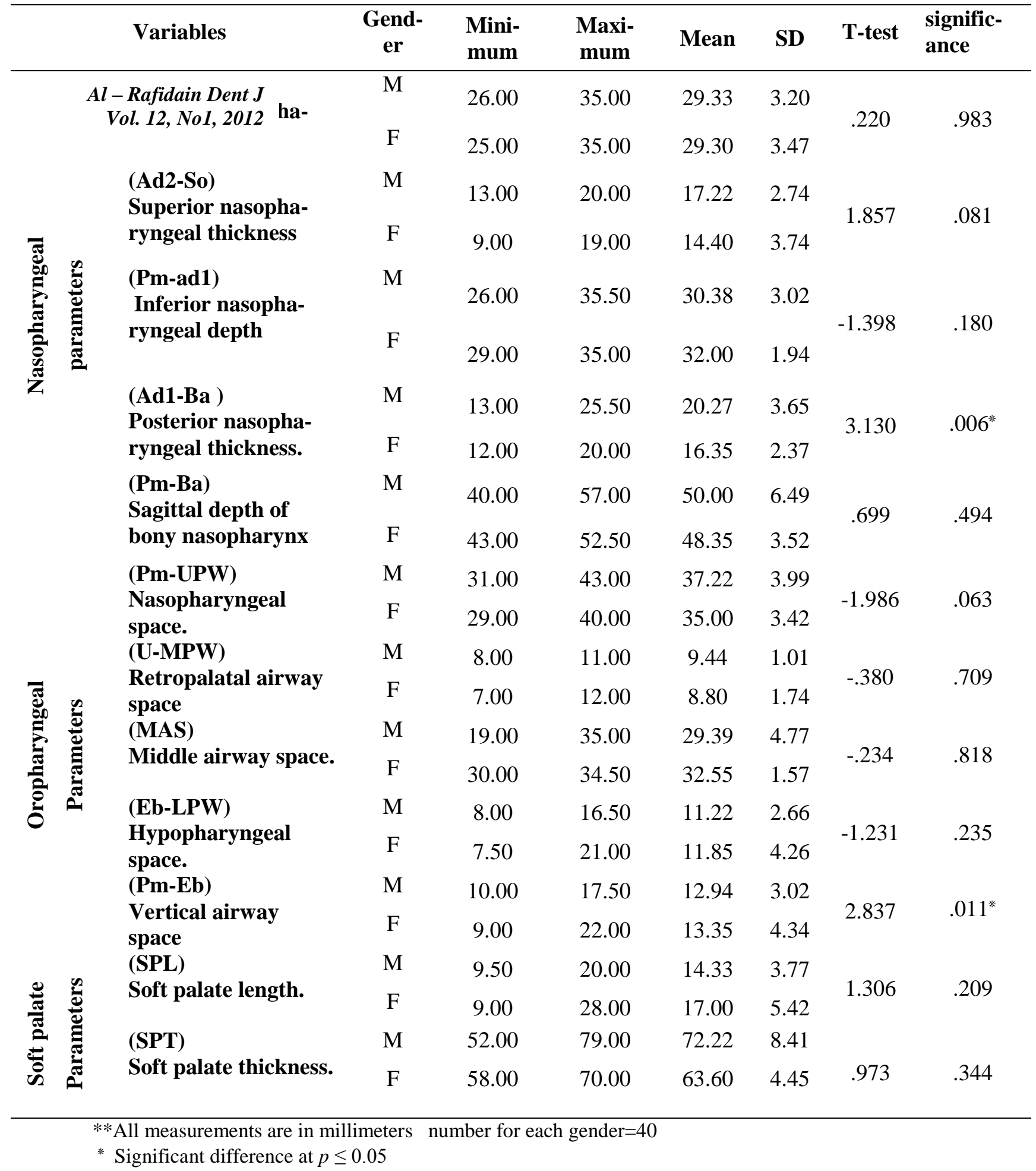


Table (3): Descipitive statistics of pharynx and soft palate in the total adolescents and adults.

\begin{tabular}{|c|c|c|c|c|c|c|}
\hline & Variable & Age & $\begin{array}{l}\text { Mini- } \\
\text { mum }\end{array}$ & $\begin{array}{l}\text { Maxi- } \\
\text { mum }\end{array}$ & Mean & $\begin{array}{l}\text { Stdan- } \\
\text { derdDevia- } \\
\text { tion }\end{array}$ \\
\hline \multirow{10}{*}{ 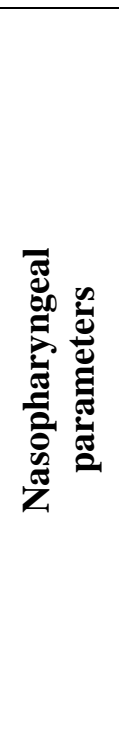 } & \multirow{4}{*}{$\begin{array}{l}\text { (Pm-ad2) } \\
\text { Superior nasopharyn- } \\
\text { geal depth } \\
\text { (Ad2-So) } \\
\text { Superior nasopharyn- } \\
\text { geal thickness }\end{array}$} & Adolescent & 14.00 & 27.00 & 20.34 & 3.61 \\
\hline & & Adult & 25.00 & 35.00 & 29.32 & 3.25 \\
\hline & & Adolescent & 16.00 & 29.00 & 24.24 & 3.54 \\
\hline & & Adult & 9.00 & 20.00 & 15.74 & 3.53 \\
\hline & \multirow{2}{*}{$\begin{array}{l}\text { (Pm-ad1) } \\
\text { Inferior nasopharyn- } \\
\text { geal depth }\end{array}$} & Adolescent & 20.00 & 33.00 & 27.48 & 3.87 \\
\hline & & Adult & 26.00 & 35.50 & 31.24 & 2.57 \\
\hline & \multirow{2}{*}{$\begin{array}{l}\text { (Ad1-Ba ) } \\
\text { Posterior nasopharyn- } \\
\text { geal thickness. }\end{array}$} & Adolescent & 15.00 & 34.00 & 24.03 & 4.08 \\
\hline & & Adult & 12.00 & 25.50 & 18.42 & 3.71 \\
\hline & \multirow{2}{*}{$\begin{array}{l}(\text { Pm-Ba }) \\
\text { Sagittal depth of bony } \\
\text { nasopharynx }\end{array}$} & Adolescent & 37.00 & 61.00 & 50.40 & 5.22 \\
\hline & & Adult & 40.00 & 57.00 & 49.13 & 5.07 \\
\hline \multirow{10}{*}{ 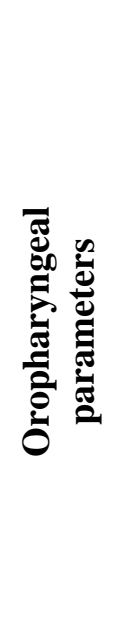 } & \multirow{2}{*}{$\begin{array}{l}\text { (Pm-UPW) } \\
\text { Nasopharyngeal space. }\end{array}$} & Adolescent & 23.00 & 36.00 & 29.55 & 3.55 \\
\hline & & Adult & 19.00 & 35.00 & 31.05 & 3.74 \\
\hline & \multirow{4}{*}{$\begin{array}{l}\text { Retropalatal airway } \\
\text { space } \\
\text { (MAS) } \\
\text { Middle airway space. }\end{array}$} & Adolescent & 6.00 & 21.00 & 12.23 & 3.60 \\
\hline & & Adult & 7.50 & 21.00 & 11.55 & 3.51 \\
\hline & & Adolescent & 8.00 & 20.00 & 13.73 & 3.54 \\
\hline & & Adult & 9.00 & 22.00 & 13.16 & 3.67 \\
\hline & \multirow{2}{*}{$\begin{array}{l}\text { (Eb-LPW) } \\
\text { Hypopharyngeal space. }\end{array}$} & Adolescent & 7.00 & 26.00 & 17.28 & 5.46 \\
\hline & & Adult & 9.00 & 28.00 & 15.74 & 4.78 \\
\hline & \multirow{2}{*}{$\begin{array}{l}\text { (Pm-Eb) } \\
\text { Vertical airway space }\end{array}$} & Adolescent & 45.00 & 70.00 & 59.73 & 5.40 \\
\hline & & Adult & 52.00 & 79.00 & 67.68 & 7.80 \\
\hline \multirow{4}{*}{ 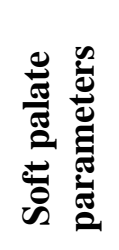 } & \multirow{2}{*}{$\begin{array}{l}\text { (SPL) } \\
\text { Soft palate length. }\end{array}$} & Adolescent & 26.00 & 48.00 & 35.13 & 5.24 \\
\hline & & Adult & 29.00 & 43.00 & 36.05 & 3.77 \\
\hline & \multirow{2}{*}{$\begin{array}{l}\text { (SPT) } \\
\text { Soft palate thickness. }\end{array}$} & Adolescent & 8.00 & 13.50 & 10.48 & 1.44 \\
\hline & & Adult & 7.00 & 12.00 & 9.11 & 1.44 \\
\hline
\end{tabular}

**All measurements are in millimeters number for adolescent $=80$
*Significant difference at $p \leq 0.05$

number for adult $=80$ 
Table (4):Comparison of pharynx and soft palate between adolescents and adult in males.

\begin{tabular}{|c|c|c|c|c|c|c|c|}
\hline & Variables & $\begin{array}{c}\text { Adol } \\
\text { (numl }\end{array}$ & $\begin{array}{l}\text { ents } \\
r=40)\end{array}$ & $\underset{\text { (num }}{\mathrm{A}}$ & $\begin{array}{l}\text { ts } \\
=40)\end{array}$ & T value & \\
\hline & & mean & SD & mean & SD & T value & significancy \\
\hline & $\begin{array}{l}(\text { Pm-ad2) } \\
\text { Superior nasopha- } \\
\text { ryngeal depth } \\
(\text { Ad2-So) }\end{array}$ & 19.67 & 4.15 & 29.33 & 3.20 & -5.53 & $.000 *$ \\
\hline 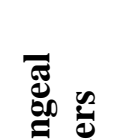 & $\begin{array}{l}\text { Superior nasopha- } \\
\text { ryngeal thickness }\end{array}$ & 25.72 & 4.06 & 17.22 & 2.74 & 5.20 & $.000 *$ \\
\hline 苛 & $\begin{array}{l}\text { Inferior nasopha- } \\
\text { ryngeal depth }\end{array}$ & 26.88 & 3.69 & 30.39 & 3.02 & -2.20 & $.043^{*}$ \\
\hline$\tilde{z}^{\mathscr{n}}$ & $\begin{array}{l}\text { (Ad1-Ba ) } \\
\text { Posterior nasopha- } \\
\text { ryngeal thickness. } \\
\text { (Pm-Ba) }\end{array}$ & 25.33 & 3.12 & 20.72 & 3.65 & 2.88 & $.011^{*}$ \\
\hline & $\begin{array}{l}\text { Sagittal depth of } \\
\text { bony nasopharynx } \\
\text { (Pm-UPW) }\end{array}$ & 49.77 & 6.72 & 50.00 & 6.49 & -.071 & .944 \\
\hline & $\begin{array}{l}\text { Nasopharyngeal } \\
\text { space. } \\
\text { (U-MPW) }\end{array}$ & 28.44 & 3.39 & 29.39 & 4.77 & -.484 & 635 \\
\hline 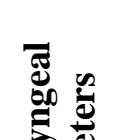 & $\begin{array}{l}\text { Retropalatal airway } \\
\text { space } \\
\text { (MAS) }\end{array}$ & 10.50 & 2.49 & 11.22 & 2.66 & -.595 & .560 \\
\hline 节 & Middle airway space. & 12.39 & 3.32 & 12.94 & 3.02 & -.372 & .715 \\
\hline$\tilde{b}^{2}$ & $\begin{array}{l}\text { (Eb-LPW) } \\
\text { Hypopharyngeal } \\
\text { space. } \\
(\text { Pm-Eb) }\end{array}$ & 16.39 & 6.24 & 14.33 & 3.77 & .847 & .410 \\
\hline & $\begin{array}{l}\text { Vertical airway } \\
\text { space } \\
\text { (SPL) }\end{array}$ & 60.72 & 3.54 & 72.22 & 8.21 & -3.782 & $.002 *$ \\
\hline$\stackrel{\mathscr{E}}{\mathscr{E}}$ & Soft palate length. & 37.39 & 4.56 & 37.22 & 3.99 & .082 & .935 \\
\hline 常 & Soft palate thickness. & 10.17 & 1.37 & 9.44 & 1.01 & 1.27 & .223 \\
\hline
\end{tabular}

**All measurements are in millimeters

* Significant difference at $p \leq 0.05$ 
Table (5): Comparison of pharynx and soft palate between adolescents and adult in females.

\begin{tabular}{|c|c|c|c|c|c|c|c|}
\hline & \multirow{2}{*}{ Variables } & \multicolumn{2}{|c|}{$\begin{array}{c}\text { Adolescents } \\
\text { (number=80) }\end{array}$} & \multicolumn{2}{|c|}{$\begin{array}{c}\text { Adults } \\
\text { (number }=80)\end{array}$} & \multirow[t]{2}{*}{ T value } & \multirow{2}{*}{$\begin{array}{l}\text { significan- } \\
\text { cy }\end{array}$} \\
\hline & & mean & SD & mean & SD & & \\
\hline \multirow{6}{*}{ 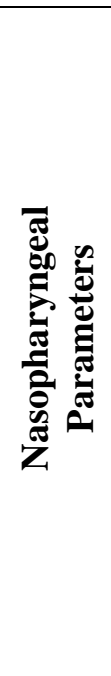 } & (Pm-ad2) & & & & & & \\
\hline & $\begin{array}{l}\text { Superior nasopha- } \\
\text { ryngeal depth } \\
\text { (Ad2-So) }\end{array}$ & 22.28 & 3.15 & 28.89 & 3.41 & -4.92 & $.000 *$ \\
\hline & $\begin{array}{l}\text { Superior nasopha- } \\
\text { ryngeal thickness }\end{array}$ & 22.61 & 2.47 & 15.00 & 3.42 & 5.41 & $.000^{*}$ \\
\hline & $\begin{array}{l}\text { (Pm-ad1) } \\
\text { Inferior nasopha- } \\
\text { ryngeal depth } \\
\text { (Ad1-Ba ) }\end{array}$ & 28.28 & 4.35 & 31.89 & 2.03 & -2.26 & $.038 *$ \\
\hline & $\begin{array}{l}\text { Posterior nasopha- } \\
\text { ryngeal thickness. } \\
\text { (Pm-Ba) }\end{array}$ & 23.39 & 4.98 & 16.28 & 2.50 & 3.83 & $.001 *$ \\
\hline & $\begin{array}{l}\text { Sagittal depth of } \\
\text { bony nasopharynx } \\
\text { (Pm-UPW) }\end{array}$ & 51.67 & 3.83 & 48.12 & 3.28 & 1.98 & .066 \\
\hline \multirow{5}{*}{ 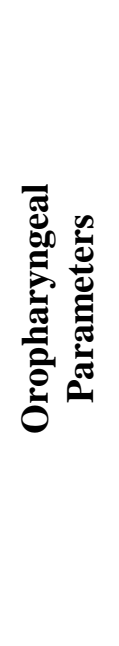 } & $\begin{array}{l}\text { Nasopharyngeal } \\
\text { space. } \\
\text { (U-MPW) }\end{array}$ & 30.50 & 3.95 & 32.50 & 1.66 & -1.40 & .181 \\
\hline & $\begin{array}{l}\text { Retropalatal airway } \\
\text { space } \\
\text { (MAS) }\end{array}$ & 13.39 & 3.54 & 11.78 & 4.51 & .842 & .412 \\
\hline & $\begin{array}{l}\text { Middle airway } \\
\text { space. }\end{array}$ & 15.22 & 3.77 & 13.50 & 4.57 & .872 & .396 \\
\hline & $\begin{array}{l}\text { (Eb-LPW) } \\
\text { Hypopharyngeal } \\
\text { space. } \\
\text { (Pm-Eb) }\end{array}$ & 19.11 & 3.71 & 17.50 & 5.50 & .728 & .477 \\
\hline & $\begin{array}{l}\text { Vertical airway } \\
\text { space } \\
\text { (SPL) }\end{array}$ & 58.33 & 7.25 & 63.00 & 4.27 & -1.66 & .115 \\
\hline \multirow{2}{*}{ 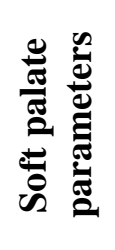 } & Soft palate length. & 34.44 & 5.03 & 35.00 & 3.63 & -.27 & .792 \\
\hline & $\begin{array}{l}(\mathrm{SPT}) \\
\text { Soft palate } \\
\text { thickness. }\end{array}$ & 10.17 & 1.37 & 9.44 & 1.01 & 2.39 & $.030 *$ \\
\hline
\end{tabular}

**All measurements are in millimeters * Significant difference at $p \leq 0.05$

\section{DISCUSSION}

The nasopharynx consists of group of muscular organs. The size and Shape of nasopharynx depend on the surrounding bony structures, of which the base of the cranium bone is the most significant part. The oropharyngeal area is the only collapsible segment of the upper airway because its walls are not sufficiently rigid for giving protection against negative trans- mural pressure. ${ }^{(20)}$ Without bony or cartilaginous structures that was the reason why it focused on developmental changes over the different sites in the pharyngeal airway. In this study, only subjects with normal vertical relationship were included to eliminate any effect on nasopharyngeal airway caused by changes in the vertical plane. ${ }^{(21)}$ Cephalometric norms for nasopharyngeal measurements were also re- 
ported Pool et al norms ${ }^{(22)}$ were calculated for various ages (6-16) and both gender and found to vary according to age and gender .The cephalometric measurements of the upper airway in these groups are thus appropriate to use a normative data for future comparison.

Sex differences were not detected in soft palate dimensions. Pharyngeal dimensions were not affected by sex except in adolescents where (U-MPW) was longer in males. These findings are in agreement with those reported in the literatures ${ }^{3,6}$ ,23,24) which suggest that sex differences in the pharyngeal dimensions are not present and in contrast to Samman et $a l^{(18)}$ and Sheng et $a l .{ }^{(5)}$ However, vertical airway length and thickness of the soft tissue on the posterior nasopharyngeal wall showed sex differences in adults. This indicate these dimensions increased more with age in males than in females; therefore, a smaller dimensions in males during adolescents produced no sexual difference, and more obvious sexual dimorphism appeared in adulthood.

The nasopharyngeal dimensions continue to grow rapidly until 13 years of age 25 and then slow until adulthood. ${ }^{(6)}$ In this study, include the adolescent and adults to ensure if differences had existed between these groups. Tourne, ${ }^{(25)}$ stated that the nasopharyngeal depth is formed at early Ages and then it usually remains the same during the life time. But, it also has been stated, that nasopharynx continues to increase in the width until adulthood. Kollas and Krogstad ${ }^{(27)}$ found that sagittal dimension of pharynx and the minimal distance between the base of the tongue and the posterior pharyngeal wall decrease during adulthood. Martin et al, ${ }^{(28)}$ concluded that all upper airway dimensions, except the oropharyngeal junction decreased with increasing age in both men and women, while the study of Sheng et al revealed that the depth of the pharyngeal airway significantly increased from childhood to young adulthood in both genders, except that of the retroglossal-pharyngeal airway depth in females. The average chronologic age of their subjects was younger than that of Martin's subjects, and the difference between the two studies implies that the developmental pattern of the pharyn- geal sagittal depth in young.

people might differ from that in middle-age persons The present study showed that the adults had a significantly higher value for $(\mathrm{Pm}-\mathrm{ad} 2)$ and $(\mathrm{ad} 1-\mathrm{Ba})$, while the adolescents had higher value for (ad2So) and (ad1-Ba) than adults in both genders. The possible explanation for this is the prosses of displacement. ${ }^{(29)}$ Causes the maxillary complex to move anteriorly and inferiorly from the cranium by expansion and growth of the soft tissues in the mid facial area and From the remodling growth concept of Enlow. ${ }^{(29)}$ the palate grew downward by periosteal resorption on the nasal side and deposition on the oral side. This growth and remodling process helps enlargement of the nasal chambers and development of the vertical enlargement of the nasal region.The Ptergomaxillary $(\mathrm{Pm})$ moved forwad and increased the distance from $\mathrm{Pm}$ to ad1.Linder-Aronson. ${ }^{(23)}$ Found that the thickness of the posterior nasopharyngeal wall(ad1-Ba)Was less than the inferior nasopharyngeal depth (Pm-ad1) due to $\mathrm{Ba}$ movement more saggitaly than did Pm during the period of growth in his observation.

Furthermore, the (Pm-Eb) in this study increased more with age in males, while the (SPT) decreased more with age in females.

The difference in growth between the female and male due to the basic difference in size after puberty due to male growth taking place for a longer period and to a larger size than for females at comparable ages. ${ }^{(29)}$ Handelman and Osborne. ${ }^{(6)}$ Billing and co-worker. ${ }^{(30)}$ stated that genetic factors had a notable influence on the dimensions of pharyngeal space ,the thickness of the posterior pharyngeal wall and the nasopharyngeal airway.

\section{CONCLUSIONS}

Data derived from this study should be a useful reference for assessment of sleep apnoea and other conditions in the Iraqi population. The only significant gender differences were found in the nassopharyngeal space in the adolescents and thickness of posterior nasopharyngeal wall and in the vertical airway space in the adults. Developmental changes were 
found in superior and inferior nasopharyngeal depth, superior and posterior nasopharyngeal thickness, vertical airway space and soft palate thickness.

\section{REFERENCES}

1. Hiatt JL, Gartner LP. Textbook of Head and Neck Anatomy. New York, NY: Appleton-Century-Crofts; 1982: 48-56.

2. Schwab RJ. Upper airway imaging. Clin Chest Med. 1998; 19:33-54.

3. Abu Allhaija ES,Al-Khateeb SN.Uvula-glosso-pharyngeal dimensions in different anteroposterior skeletal patterns.Angle Orthod. 2004; 75(6): 1012-1018.

4. Joseph AA, Elbaum J, Cisneros GJ, Eisig SB. A cephalometric comparative study of the soft tissue airway dimensions in persons with hyperdivergent and normodivergent facial patterns. $J$ Oral Maxillofac Surg. 1998; 56:135139.

5. Sheng MSh,lin LH,Su Y,Tsai HH.Developmental changes in pharyngeal airway depth and hyoid bone position from childhood to young adulthood. Angle Orthod. 2008; 79 (3):484490.

6. Handelman CS, Osborne G. Growth of the nasopharynx and adenoid development from one to eighteen years. Angle Orthod.1976; 46:243-259

7. Tsai HH. Developmental changes of pharyngeal airway structures from young to adult persons. $J$ Clin Pediatr Dent. 2007; 31:221-223.

8. Figueroa AA, Glupker TJ, Fitz MG, Begole EA. Mandible ,tongue and airway in Pierre Robin sequence: a longitudinal cephalomtric study. Cleft Palate Craniofac J. 1991; 28:425-34.

9. Hoekema A, Hovinga B, Stegenga B, De Bont LGM. Craniofacial morphology and obstructive sleep apnoea: a cephalometric analysis. J Oral Rehabil. 2003; 30:690-696.

10.Tsai HH, Ho CY, Lee PL, Tan CT. Cephalometric analysis of nonobese snorers either with or without obstructive sleep apnea syndrome. Angle Orthod. 2007; 77:1054-1061.

11. Nicole E, Koord S, Alexander J, Akram R, Urs T, Tateyuki I. Long-term changes of hyoid bone and pharyngeal airway size following advancement of the mandible. Oral Surg Oral Med Oral Pathol Oral Radiol Endod. 2005; 99:404-410.

12.Nicole E, Wenko S, Tateyuki I. Longterm changes of hyoid bone position and pharyngeal airway size following mandibular setback by sagittal split ramus osteotomy. J Craniomaxillofac Surg. 2005; 33:111-117.

13. Archilleos S, Krogstad O, Lyberg T. Surgical mandibular advancement and changes in uvuloglossopharyngeal morphology and head posture: a shortand long-term cephalometric study in males. Eur J Orthod. 2000; 22: 367381.

14. Surtt PM, Dee P, Atkinson RL, Armstrong P, Wihoit SC. Fluoroscopic and computed tomographic features of the pharyngeal airway in obstructive sleep apnea. Am Rev Respir Dis 1983; 127: 487-92.

15.Pepin JL, Ferretti G, Veale D. Somnofluoroscopy, computed tomography, and cephalometry in the assessment of the airway in obstructive sleep apnoea. Thorax. 1992 ; 47:150-6.

16.deWberry-Borowiecki B, Kukwa A, Blanks RH. Cephalomtric analysis for diagnosis and treatment of obstructive sleep apnea. Laryngoscope. 1988; 98: 226-34.

17.Shen GF, SammanN, Qiu WL, Tang YS, Xia J, Huang L. Cephalometric studies on the upper airway space in normal Chinese. Int.J Oral Maxillofac Surg. 1994; 23:243-7

18. Sammon N, Mohammadi H, Xia J. Cephalometric norms for the upper airway in a healthy Hong Kong Chinese population. Hong Kong Med J. 2003; 9:2530.

19. Charoenworaluck N. A Cephalometric comparison of pharynx and soft palate in subjects treated with rapid maxillary expansion.A thesis submitted to Ludwig-Maximilians-Universitat $\mathrm{Zu}$ Munchen ; 2006 .

20.Low AA.The tongue and airway. Otolaryngol clin North Am.1990; 23: 677698

21. Opdebeeck H, Bell WH, Eisenfeld J, Mishelevich D. Comparative study be- 
tween the SFS and LFS rotation as a possible morphogenic mechanism. Am J Orthod. 1978; 74:509-521.

22.Pool MN,Engel GA,Chaconas SJ.Nasopharyngeal cephalometrics. Oral Surg Oral Med Oral Pathol. 1980; 49:266-71.

23. Linder-Aronson, S., Leighton, BC.:A longitudinal study of the development of the posterior nasopharyngealwall between 3 and 16 years of age. Eur J Orthod. 1983; 5:47-58.

24.ceylan I,Oktay H.Astudy on the pharyngeal size in different skeletal patterns. Am J Orthod Dentofacial Orthop.1995,108:69-75.

25.Tourné LPM. Growth of the pharynx and its physiologic implications. Am J Orthod. Dentofacial Orthop. 1991; 99:129-139.

26.Jeans WD, Fernando DCJ, Maw AR, Leighton BC. A longitudinal study of the growth of the nasopharynx and its contents in normal children. $\mathrm{Br} \mathrm{J}$ Radiol. 1981; 54:117-121.

27.Koiiias I,Krogstad O.Adult craniocervical and pharyngeal changes-a longitudinal cephalometric study between 22 and 42 years of age . Part II: morphological uvula-glosspharyngeal changes. Eur J Ohod.1999 ; 21:345-5

28. Martin SE, Mathur R, Marshall I, Douglas NJ. The effect of age, sex, obesity and posture on upper airway size. Eur Respir J.1997; 10: 2087- 2090.

29.Enlow, DH.:Facial growth W.B. Sounders Company, Philadelphia, 3rd edition, 1990

30.Billing, $\mathrm{H}$, Leighton, BC, LinderAronson, S, Lundström, A, McWilliam, J.The development of the pharyngeal space and lymphoid tissue on teheposterior nasopharyngeal wall- an assessment with regard to heritability. Eur J Orthod. 1988; 10:106-110. 